\title{
Mutagenic Activity of Tea Flavonoid (-)-Epigallocatechin in Bacterial and Mammalian Cells
}

\author{
Kunio Wada ${ }^{1}$ and Kyomu Matsumoto \\ Laboratory of Genetic Toxicology, The Institute of Environmental Toxicology, Ibaraki, Japan
}

(Received December 15, 2008; Revised February 2, 2009; Accepted February 17, 2009)

\begin{abstract}
Animal studies have revealed that tea flavonoids, known as catechins, have the potential to prevent cancer. We investigated the genotoxicity of the 4 main green tea catechins, namely, (-)-epigallocatechin gallate (EGCG), (-)-epigallocatechin (EGC), (-)-epicatechin gallate (ECG), and $(-)$-epicatechin (EC), using the comet assay in Chinese hamster $\mathrm{CHL} / \mathrm{IU}$ cells. By measuring the percent of DNA in the comet tail, we concluded that EC, ECG, and EGCG did not induce biologically significant DNA damage. In contrast, EGC induced strong DNA damage at concentrations of $100 \mu \mathrm{M}$ or higher. We further examined the genotoxic ability of EGC by the reverse mutation assay and the in vitro chromosome aberration test. The reverse mutation assay, revealed a maximum of 1.8-fold increase in the mean number of revertant colonies at $5000 \mu \mathrm{g} /$ plate of EGC as compared to the number of colonies in the solvent control in Escherichia coli WP2uvrA/pKM101. EGC caused chromosome aberrations at low frequency in $\mathrm{CHL} / \mathrm{IU}$ cells at a concentration of $200 \mu \mathrm{M}$. We concluded that EGC was weakly mutagenic in bacterial and mammalian cells.
\end{abstract}

Key words: green tea catechin, (-)-epigallocatechin, comet assay, reverse mutation assay, cytogenetic assay

\section{Introduction}

Tea flavonoids, known as catechins, have received considerable attention from researchers owing to their possible beneficial health effects. Four major catechins are found in tea: (-)-epigallocatechin gallate (EGCG), $(-)$-epigallocatechin (EGC), (-)-epicatechin gallate (ECG), and (-)-epicatechin (EC) (Fig. 1). Green tea contains larger amounts of these catechins than other fermented teas. For example, Sencha (the most common green tea in Japan) extract in hot water contains each of these catechins in the concentration range 6-99 $\mathrm{mM}(1)$. Although the cancer-preventive effects of green tea have been widely confirmed by epidemiological, cell culture, animal, and clinical studies (2), green tea catechins have been reported to enhance colon carcinogenesis in rats (3). Furthermore, several human cohort and case-control studies have indicated significant positive relationships between tea consumption and cancers of various organs (4-6).

Kuroda et al. (7-9) have focused on antimutagenic and anticarcinogenic activity of tea polyphenols. EGCG is expected to exhibit the highest cancer preventive effects among tea catechins (10), but it also induces DNA damage in human lymphocytes (11), produces active oxygen species by auto-oxidation (12), and causes chromosome aberrations in mammalian cells (13). These findings indicate that EGCG has multiple functions, which includes both beneficial and nonbeneficial effects. While the genotoxicity of EGCG has been well investigated, that of the other catechins has not. Therefore, we examined the genotoxicity of the catechins, namely, EGC, ECG, and EC as well as EGCG, by the in vitro comet assay to reveal their potential of inducing DNA damage. Since the result for EGC was clearly positive, we carried out additional in vitro genotoxic studies (i.e., the reverse mutation assay and the chromosome aberration test). All experiments were conducted in the absence of a metabolic activation system because tea catechins are hardly absorbed into the blood after ingestion of green tea by humans (14) and most catechins do not undergo metabolic activation in the liver.

\section{Materials and Methods}

Chemicals: The 4 catechins, EGCG (CAS no. 989-51-5, 90.0\% pure), EGC (CAS no. 970-74-1, 98.0 $\%$ pure), ECG (CAS no. 1257-08-5, 98.0\% pure), and EC (CAS no. 490-46-0, 98.0\% pure), were purchased from Wako Pure Chemical Industries, Ltd., Osaka, Japan. EGCG, EGC, and EC were dissolved in physiological saline (Otsuka Pharmaceutical Factory, Inc., Tokushima, Japan). ECG was dissolved directly in the growth medium immediately before use.

Bacterial strain and mammalian cells: Escherichia coli WP2uvrA/pKM101 (trpE65, uvrA, pKM101), which can detect oxidative mutagens (15), was used for

\footnotetext{
${ }^{1}$ Correspondence to: Kunio Wada, Laboratory of Genetic Toxicology, The Institute of Environmental Toxicology, 4321 Uchimoriya-machi, Joso-shi, Ibaraki 303-0043, Japan. Tel: +81-297-27-4539, Fax: + 81-297-27-4518, E-mail: wada@iet.or.jp
} 
<smiles>Oc1cc(O)c2c(c1)O[C@H](c1ccc(O)c(O)c1)[C@H](O)C2</smiles>

(-)-Epicatechin (EC)<smiles>Oc1cc(O)c2c(c1)O[C@H](c1cc(O)c(O)c(O)c1)[C@H](O)C2</smiles>

(-)-Epigallocatechin (EGC)<smiles>O=C(O[C@@H]1Cc2c(O)cc(O)cc2O[C@H]1c1ccc(O)c(O)c1)c1cc(O)c(O)c(O)c1</smiles>

(-)-Epicatechin gallate (ECG)<smiles>O=C(O[C@H]1Cc2c(O)cc(O)cc2O[C@H]1c1cc(O)c(O)c(O)c1)c1cc(O)c(O)c(O)c1</smiles>

(-)-Epigallocatechin gallate (EGCG)

Fig. 1. The structure of the 4 main green tea catechins.

the reverse mutation assay. The strain was cultured in $2.5 \%$ nutrient broth (Oxoid nutrient broth No. 2; Oxoid Ltd., Hampshire, UK) at $37^{\circ} \mathrm{C}$ with shaking. Chinese hamster CHL/IU cells (16) were used for the comet and cytogenetic assays. They were grown in Eagle's minimal essential medium (MEM; GIBCO ${ }^{\mathbb{R}}$, Invitrogen Corp., CA, USA) supplemented with $10 \%$ newborn calf serum $\left(\mathrm{GIBCO}^{\mathbb{R}}\right), 2 \mathrm{mM}$ L-glutamine, 100 units/mL penicillin, and $100 \mu \mathrm{g} / \mathrm{mL}$ streptomycin in a humidified atmosphere with $5 \% \mathrm{CO}_{2}$ at $37^{\circ} \mathrm{C}$. The growth medium contained phenol red as a $\mathrm{pH}$ indicator. The doubling time of the cells was $15-16 \mathrm{~h}$ under these conditions.

Comet assay: Cells were treated with each catechin for $1 \mathrm{~h}$ in the absence of a metabolic activation system. The plates were prepared in duplicates for each concentration of the catechin. The comet assay was conducted under alkaline conditions as described in Tice et al. (17). $\mathrm{CHL} / \mathrm{IU}$ cells were harvested by $0.25 \%$ trypsin and suspended in the mincing buffer $\left(20 \mathrm{mM} \mathrm{Na} \mathrm{NaDTA}_{2}\right.$ and $10 \%$ DMSO in Hank's balanced salt solution). The cell suspension was mixed with $0.75 \%$ low melting point agarose (Nacalai Tesque, Kyoto, Japan). The mixture containing the cells and agarose was dropped on a bottom layer of $0.75 \%$ normal melting point agarose (Nacalai Tesque) on glass slides (Matsunami, Osaka, Japan). Two slides were prepared for each sample; they were coded, and the agarose was allowed to solidify at $4^{\circ} \mathrm{C}$ for $7 \mathrm{~min}$. Then, the slides were immersed in lysis solution $(2.5 \mathrm{M} \mathrm{NaCl}, 100 \mathrm{mM} \mathrm{Na} 2 \mathrm{EDTA}, 10 \mathrm{mM}$ Tris$\mathrm{HCl}, 1 \%$ Triton $\mathrm{X}-100$, and $10 \%$ DMSO) at $4{ }^{\circ} \mathrm{C}$ for more than $1 \mathrm{~h}$. Next, the slides were rinsed with pure water and placed in electrophoresis buffer $(0.3 \mathrm{M} \mathrm{NaOH}$ and $1 \mathrm{mM} \mathrm{Na} \mathrm{N}_{2}$ EDTA; $\mathrm{pH} 13$ ) for $20 \mathrm{~min}$ at $4{ }^{\circ} \mathrm{C}$ to allow the DNA to unwind. Electrophoresis was conducted in a horizontal electrophoresis platform in fresh, chilled electrophoresis buffer for $20 \mathrm{~min}$ at $270-300 \mathrm{~mA}$ and $0.96 \mathrm{~V} / \mathrm{cm}$. The slides were neutralized with Tris- $\mathrm{HCl}$ buffer (pH 7.5) for $5 \mathrm{~min}$, dehydrated by immersion into absolute ethanol for $5 \mathrm{~min}$, and stained with $0.2 \%$ ethidium bromide. Two hundred cells per concentration were analyzed with an Orimpas fluorescence microscope equipped with an automatic digital analysis system, Komet 5.5 (Andor Technology, Belfast, UK) and the percent of DNA in the comet (\% tail DNA), which was the most suitable measurement parameter of the DNA break frequency was determined. The \% tail DNA was compared between the treatments by using Dunnett's test after one-way analysis of variance (ANOVA) at $p=$ 0.05 . The ATP content, which was determined by the addition of luciferin-luciferase reagent with a luminometer (Lumitester C-100LU; Kikkoman), was used as an indicator of cell viability. The relative cell viability was obtained by comparison with the viability in the concurrent solvent control.

Reverse mutation assay: The bacterial reverse mutation assay was conducted using the preincubation 
method (18). Aliquots of an overnight culture $(0.1 \mathrm{~mL})$ of the tester strain and $0.1 \mathrm{~mL}$ of chemical solution(s) were added to $0.5 \mathrm{~mL}$ of $100 \mathrm{mM}$ phosphate buffer $(\mathrm{pH}$ 7.4). After preincubation at $37^{\circ} \mathrm{C}$ for 20 min with shaking, $2 \mathrm{~mL}$ of molten top agar $(0.6 \%$ agar and $0.5 \%$ $\mathrm{NaCl}$ ) containing $0.05 \mathrm{mM}$ L-tryptophan was added and overlaid on minimal glucose agar plates (AM-N plates; Oriental Yeast Co., Ltd., Tokyo, Japan). Trp ${ }^{+}$ revertant colonies were counted after incubation at $37^{\circ} \mathrm{C}$ for 2 days. The plates were prepared in triplicates for each concentration of EGC.

Cytogenetic assay: Exponentially growing cells were treated with EGC in the absence of a metabolic activation system. Three hours after the treatment was initiated, all cultures were rinsed twice with PBS and cultured for an additional $21 \mathrm{~h}$ in fresh medium. Colcemid ${ }^{\mathbb{R}}$ (Wako) was added to the cultures at the final concentration of $0.2 \mu \mathrm{g} / \mathrm{mL} 2 \mathrm{~h}$ before harvesting the metaphase cells. The conventional air-drying method was used for chromosome preparations. Cells were detached with $0.25 \%$ trypsin and swollen with a hypotonic solution of $0.075 \mathrm{M} \mathrm{KCl}$ for approximately $10 \mathrm{~min}$ at room temperature. The cells were then fixed in methanol:acetic acid (3:1) and air-dried on glass slides. The chromosome preparations were coded and then stained with 2\% Giemsa solution (Merck Ltd., Darmstadt, Germany) for 15 min at room temperature. For chromosomal aberration analysis, 200 well-spread

EC

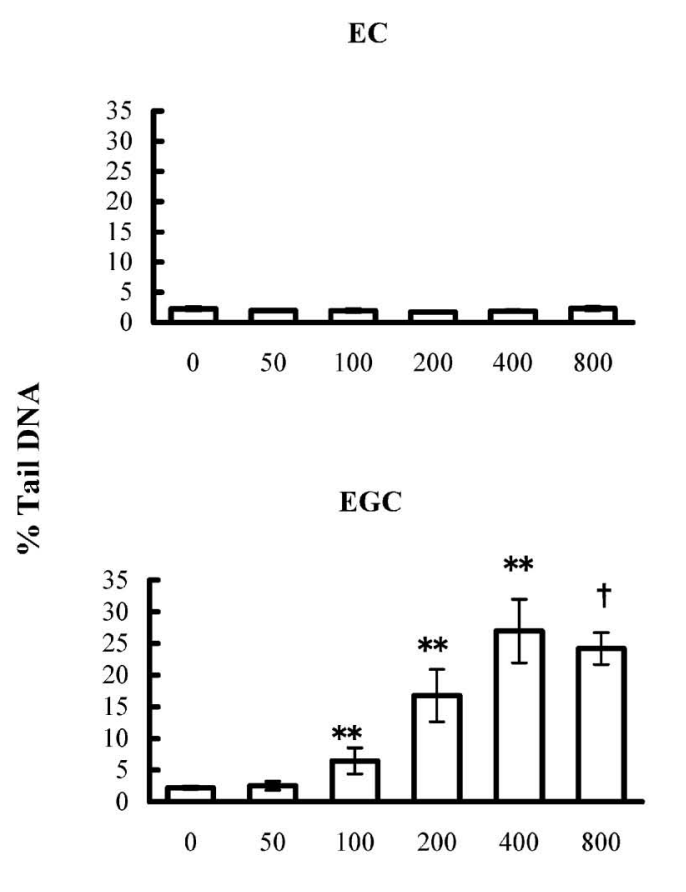

metaphase cells per concentration were examined at 1000 -fold magnification using a light microscope. The mitotic index was determined by counting 1000 cells for each concentration. The chi-square test was used to compare the data of each sample to the data of the corresponding solvent control. A $p$ value of less than 0.05 was considered statistically significant.

\section{Results}

Comet assay: EGC clearly increased the \% tail DNA at concentrations of $100 \mu \mathrm{M}$ or higher as compared to the negative control (Fig. 2). It has been recommended that concentrations that result in more than $30 \%$ reduction in the cell viability should not be used for genotoxic evaluation by comet assays because DNA damage is usually associated with excess cytotoxicity (19). We concurrently assessed the cytotoxic effect of EGC by determining the amount of ATP in the cells. We found that the cell viabilities were $100 \%, 87 \%$, $95 \%, 86 \%, 81 \%$, and $68 \%$ at $0,50,100,200,400$, and $800 \mu \mathrm{M}$ EGC, respectively. We therefore considered the results for the comet assay at $800 \mu \mathrm{M}$ as invalid. EGCG caused a slightly but statistically significant increase in the \% tail DNA at $400 \mu \mathrm{M}$ as compared to the negative control. The results for EC and ECG were negative at concentrations up to $800 \mu \mathrm{M}$ and cytotoxicity was also not observed.

Reverse mutation assay: We examined the bac-

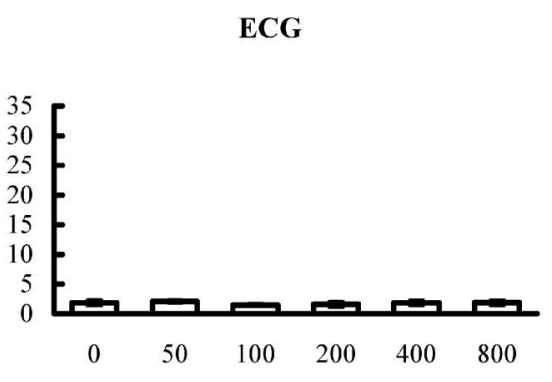

\section{Concentration $(\mu \mathrm{M})$}

Fig. 2. DNA damage measured by the in vitro comet assay in CHL/IU cells treated with green tea catechins. The error bars indicate standard deviation. ${ }^{* *}$ Significantly different from the control at $p<0.01$. $\uparrow$ indicates that cytotoxicity was also observed. 
terial mutagenic activity of EGC at doses of 39.1-5000 $\mu \mathrm{g} / \mathrm{plate}$. The background lawn did not reduce at any dose. The number of revertants gradually increased with increase in the dose and at a dose of $5000 \mu \mathrm{g} /$ plate, the number was 1.8 times greater than that in the negative control (Fig. 3). These results indicated that EGC exhibited a weak mutagenic activity.

Cytogenetic assay: No significant increase in the frequency of polyploid metaphases was observed at any concentration. In contrast, a clear increase in the number of cells with chromosome aberrations was observed at 200 and $400 \mu \mathrm{M}$ EGC after $3 \mathrm{~h}$ of treatment (Table 1). Because high cytotoxicity occurred at $400 \mu \mathrm{M}$, the chromosome aberrations observed at this concentration may have been a secondary result of cytotoxicity. These results indicated that at least EGC was weakly clastogenic in cultured mammalian cells at concentrations ap-

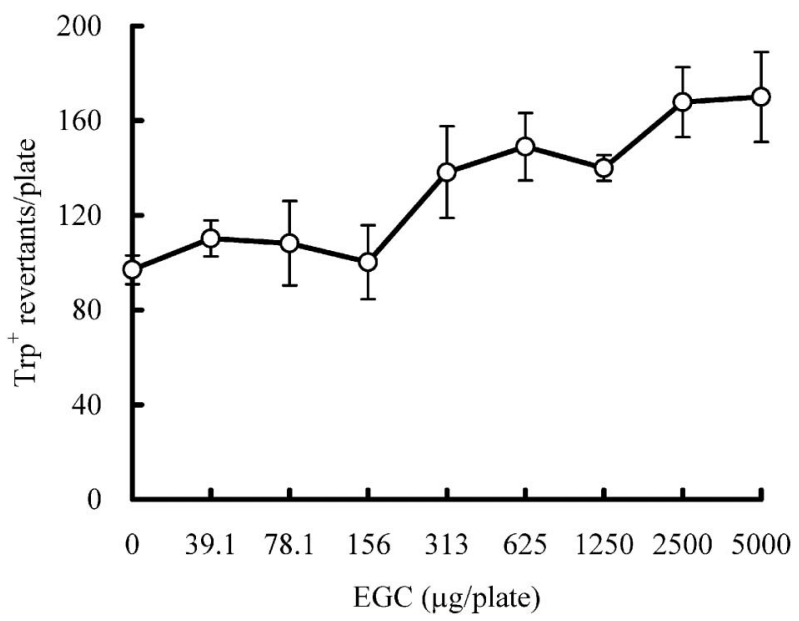

Fig. 3. Bacterial mutagenicity due to treatment with EGC in Escherichia coli WP2uvrA/pKM101. The error bars indicate standard deviation. proximating those that result in cytotoxicity.

\section{Discussion}

In our study, we obtained a clearly positive response in the comet assay and a weakly positive response in the reverse mutation assay and the chromosome aberration test for EGC. EGCG also yielded slightly but significantly positive results in the comet assay. Some reports have indicated that EGCG induces DNA damage at relatively high doses in vitro $(20,21)$. Our results seem to be consistent with these reports; however, the \% tail DNA at $400 \mu \mathrm{M}$ was very low $(3.03 \%)$ and the cell viability was only $75 \%$. On the basis of these results, the positive response of EGCG at $400 \mu \mathrm{M}$ was not considered to be biologically significant. EC and ECG yielded obviously negative results even at $800 \mu \mathrm{M}$. Furukawa et al. (12) demonstrated that the magnitude of oxidative damage to isolated DNA induced by catechins in the presence of $\mathrm{Cu}(\mathrm{II})$ is in the following order: EGC $>$ catechin $>$ EGCG $>$ ECG. This report supports our finding that the mutagenic activity of EGC was the strongest among at least the 3 catechins, suggesting that this order is applicable to cellular DNA as well.

Although our results showed that EGC induced almost no polyploidy at any concentration after $3 \mathrm{~h}$ of treatment, Neukam et al. (22) reported that EGC slightly increases the frequency of endoreduplication at concentrations of $135 \mu \mathrm{M}$ or higher in CHO-AA8 cells after $3 \mathrm{~h}$ of treatment. Currently, no data are available to explain this discrepancy, but a possible explanation is that the minimal concentration of EGC required to induce endoreduplication differs between $\mathrm{CHL} / \mathrm{IU}$ and $\mathrm{CHO}$ AA8 cells.

EGCG induces chromosome aberrations in mammalian cells (13). Furthermore, EGCG causes auto-oxi-

Table 1. Induction of chromosome aberrations in Chinese hamster CHL/IU cells treated with (-)-epigallocatechin (EGC)

\begin{tabular}{|c|c|c|c|c|c|c|c|c|c|c|c|c|c|c|}
\hline \multirow{3}{*}{ Treatment } & \multirow{3}{*}{$\begin{array}{l}\text { Concen- } \\
\text { tration } \\
(\mu \mathrm{M})\end{array}$} & \multirow{3}{*}{$\begin{array}{l}\text { No. of } \\
\text { cells } \\
\text { scored }\end{array}$} & \multirow{3}{*}{$\begin{array}{l}\text { Polyploid } \\
\text { cells }\end{array}$} & \multicolumn{9}{|c|}{ No. of cells with structural chromosome aberrations } & \multirow{3}{*}{$\begin{array}{c}\text { Mitotic } \\
\text { index } \\
(\%)\end{array}$} & \multirow{3}{*}{$\begin{array}{c}\text { Relative } \\
\text { mitotic } \\
\text { index } \\
(\%)\end{array}$} \\
\hline & & & & \multirow{2}{*}{ gap } & \multicolumn{2}{|c|}{ Chromatid type } & \multicolumn{2}{|c|}{$\begin{array}{c}\text { Chromosome } \\
\text { type }\end{array}$} & \multirow{2}{*}{ frg } & \multirow{2}{*}{ others } & \multicolumn{2}{|c|}{ Total } & & \\
\hline & & & & & ctb & cte & $\mathrm{csb}$ & cse & & & $+\mathrm{g}$ & $-\mathrm{g}$ & & \\
\hline $\begin{array}{l}\text { Physiological } \\
\text { saline }\end{array}$ & & 200 & $1(0.5)$ & $2(1.0)$ & $0(0)$ & $0(0)$ & $0(0)$ & $0(0)$ & $0(0)$ & $0(0)$ & $2(1.0)$ & $0(0)$ & 8.4 & 100 \\
\hline \multirow{5}{*}{ EGC } & 25 & 200 & $0(0)$ & $0(0)$ & $2(1.0)$ & $0(0)$ & $0(0)$ & $0(0)$ & $0(0)$ & $0(0)$ & $2(1.0)$ & $2(1.0)$ & 8.3 & 99 \\
\hline & 50 & 200 & $0(0)$ & $3(1.5)$ & $2(1.0)$ & $1(0.5)$ & $0(0)$ & $0(0)$ & $0(0)$ & $0(0)$ & $6(3.0)$ & $3(1.5)$ & 9.0 & 107 \\
\hline & 100 & 200 & $0(0)$ & $0(0)$ & $1(0.5)$ & $2(1.0)$ & $1(0.5)$ & $0(0)$ & $0(0)$ & $0(0)$ & $4(2.0)$ & $4(2.0)$ & 7.5 & 89 \\
\hline & 200 & 200 & $1(0.5)$ & $2(1.0)$ & $5(2.5)$ & $12(6.0)$ & $1(0.5)$ & $1(0.5)$ & $0(0)$ & $0(0)$ & $19(9.5)$ & $17(8.5)^{*}$ & 4.3 & 51 \\
\hline & 400 & 200 & $0(0)$ & $3(1.5)$ & $26(13)$ & 28 (14) & $2(1.0)$ & $2(1.0)$ & $0(0)$ & $2(1.0)$ & $43(21.5)$ & $40(20.0)^{*}$ & 1.1 & 13 \\
\hline
\end{tabular}

ctb, chromatid break; cte, chromatid exchange; csb, chromosome break; cse, chromosome exchange; frg, fragmentations; others, multiple aberrations; +g, including gaps; -g, excluding gaps; EGC, (-)-epigallocatechin.

The figures shown in parentheses are percentages.

* Significantly different from the control at $p<0.01$. 
dation that leads to the generation of superoxide anion and $\mathrm{H}_{2} \mathrm{O}_{2}$ (12). We assessed the mutagenic activity using E. coli WP2uvrA/pKM101 (trpE65, uvrA, pKM101), which can detect oxidative mutagens (23); thus, EGC may also have the same mode of action as EGCG.

The chemical structures of EC and EGC differ only in the number of hydroxyl groups in the B ring: $\mathrm{EC}$ has 2 hydroxyl groups (catechol) whereas EGC has 3 groups (pyrogallol) (Fig. 1). This fact indicates that the $O$-trihydroxy structure in the B ring is an important determinant of the genotoxic activity. EGCG also has the pyrogallol group in the B ring, suggesting that EGCG exhibits the genotoxic activity similar to EGC; however, EGCG was more active than EGC, as antioxidants against LDL oxidation (24). The weak response of EGCG in the comet assay seems to be due to the antioxidant property of EGCG, which modulates its auto-oxidation activity.

The mutagenicity of tea, especially green tea should be discussed because green tea contains a large amount of EGC. For example, when $1 \mathrm{~g}$ of green tea leaves from Japan is infused with $100 \mathrm{~mL}$ hot water at $100^{\circ} \mathrm{C}$, the resulting extract contains $890 \mu \mathrm{M}$ EGCG, $937 \mu \mathrm{M}$ EGC, $133 \mu \mathrm{M}$ ECG, and $324 \mu \mathrm{M}$ EC (25). Although the tea composition varies depending on many factors such as climate, type of leaves, and the procedure used for infusing tea leaves, another study also reported that each catechin is present at concentrations of few dozens to several hundred micromolar in green tea (26). In this study, we obtained positive results at approximately these concentrations of catechins. The consumption of EGC may result in mutagenic damage in the oral cavities and stomachs in humans because these organs are directly exposed to EGC. East Asians generically drink green tea not only once but several times in a day. Excessive intake of green tea may increase the risk of mutagenic damage by EGC. One of the reasons why green tea does not clearly exert a beneficial effect in humans (27) may be the mutagenic effect of EGC.

On the other hand, green tea has been consumed since ancient times as a healthy beverage; this suggests that green tea is not mutagenic in humans. Although in vivo genotoxicity tests for EGC have not been conducted, EGC may not be genotoxic in humans for the following reasons. EGC causes DNA damage via the production of hydrogen peroxide, which is easily decomposed to water and oxygen by catalase in tissues. Moreover, the low absorption rate (14) and various antioxidants (especially EGCG) present in green tea $(7-10,28)$ may modulate the genotoxic effect of EGC. These factors may support the claim that green tea is not mutagenic. We have already started to investigate the combined effects of EGC and EGCG to know whether EGCG acts as an anti-genotoxic agent against EGC.

In conclusion, EGC exhibited a weak mutagenic ac- tivity in vitro. Further studies on the mutagenic effects of EGC are required to assess the genotoxic toxicity of green tea in human.

Acknowledgements: We appreciate Mr. Yuzo Takezawa and Ms. Misaki Abe for providing technical assistance and Ms. Hitomi Takaara for critical reading of the manuscript.

\section{References}

1 Tanaka K, Hayatsu T, Negishi T, Hayatsu H. Inhibition of $N$-nitrosation of secondary amines in vitro by tea extracts and catechins. Mutat Res. 1998; 412: 91-8.

2 Chen D, Milacic V, Chen MS, Wan SB, Lam WH, Huo C, Landis-Piwowar KR, Cui QC, Wali A, Chan TH, Dou QP. Tea polyphenols, their biological effects and potential molecular targets. Histol Histopathol. 2008; 23: 487-96.

3 Hirose M, Hoshiya T, Mizoguchi Y, Nakamura A, Akagi $\mathrm{K}$, Shirai T. Green tea catechins enhance tumor development in the colon without effects in the lung or thyroid after pretreatment with 1,2-dimethylhydrazine or 2,2'-dihydroxy-di-n-propylnitrosamine in male F344 rats. Cancer Lett. 2001; 168: 23-9.

4 Kinlen LJ, Willows AN, Goldblatt P, Yudkin J. Tea consumption and cancer. Br J Cancer. 1988; 58: 397-401.

5 Lu CM, Lan SJ, Lee YH, Huang JK, Huang CH, Hsieh CC. Tea consumption: fluid intake and bladder cancer risk in Southern Taiwan. Urology. 1999; 54: 823-8.

6 Tewes FJ, Koo LC, Meisgen TJ, Rylander R. Lung cancer risk and mutagenicity of tea. Environ Res. 1990; 52: 23-33.

7 Kuroda Y, Hara Y. Antimutagenic and anticarcinogenic activity of tea polyphenols. Mutat Res. 1999; 436: 69-97.

8 Kuroda Y, Hara Y. Antimutagenic and anticarcinogenic activity of tea polyphenols (I). Environ Mutagen Res. 1999; 21: 1-10.

9 Kuroda Y, Hara Y. Antimutagenic and anticarcinogenic activity of tea polyphenols (II). Environ Mutagen Res. 1999; 21: 85-94.

10 Khan N, Mukhtar H. Multitargeted therapy of cancer by green tea polyphenols. Cancer Lett. 2008; 269: 269-80.

11 Bertram B, Bollow U, Rajaee-Behbahani N, Bürkle A, Schmezer P. Induction of poly(ADP-ribosyl)ation and DNA damage in human peripheral lymphocytes after treatment with (-)-epigallocatechingallate. Mutat Res. 2003; 534: 77-84.

12 Furukawa A, Oikawa S, Murata M, Hiraku Y, Kawanishi S. (-)-Epigallocatechin gallate causes oxidative damage to isolated and cellular DNA. Biochem Pharmacol. 2003; 66: 1769-78.

13 Sugisawa A, Umegaki K. Physiological concentrations of (-)-epigallocatechin-3-O-gallate (EGCg) prevent chromosomal damage induced by reactive oxygen species in WIL2-NS cells. J Nutr. 2002; 132: 1836-9.

14 Yang CS, Chen L, Lee MJ, Balentine D, Kuo MC, Schantz SP. Blood and urine levels of tea catechins after ingestion of different amounts of green tea by human volunteers. Cancer Epidemiol Biomarkers Prev. 1998; 7: 
351-4.

15 Wilcox P, Naidoo A, Wedd DJ, Gatehouse DG. Comparison of Salmonella typhimurium TA102 with Escherichia coli WP2 tester strains. Mutagenesis. 1990; 5: 285-91.

16 Koyama H, Utakoji T, Ono T. A new cell derived from newborn Chinese hamster lung tissue. Gann. 1970; 61: 161-7.

17 Tice RR, Agurell E, Anderson D, Burlinson B, Hartmann A, Kobayashi H, Miyamae Y, Rojas E, Ryu JC, Sasaki YF. Single cell gel/comet assay: guidelines for in vitro and in vivo genetic toxicology testing. Environ Mol Mutagen. 2000; 35: 206-21.

18 Maron DM, Ames BN. Revised methods for the Salmonella mutagenicity test. Mutat Res. 1983; 113: 173-215.

19 Henderson L, Wolfreys A, Fedyk J, Bourner C, Windebank S. The ability of the Comet assay to discriminate between genotoxins and cytotoxins. Mutagenesis. 1998; 13: 89-94.

20 Kanadzu M, Lu Y, Morimoto K. Dual function of (-)-epigallocatechin gallate (EGCG) in healthy human lymphocytes. Cancer Lett. 2006; 241: 250-5.

21 Tian B, Sun Z, Xu Z, Hua Y. Chemiluminescence analysis of the prooxidant and antioxidant effects of epigallocatechin-3-gallate. Asia Pac J Clin Nutr. 2007; 16: 153-7.
22 Neukam K, Pastor N, Cortés F. Tea flavanols inhibit cell growth and DNA topoisomerase II activity and induce endoreduplication in cultured Chinese hamster cells. Mutat Res. 2008; 654: 8-12.

23 Watanabe K, Sakamoto K, Sasaki T. Comparisons on chemically-induced mutation among four bacterial strains, Salmonella typhimurium TA102 and TA2638, and Escherichia coli WP2/pKM101 and WP2uvrA/ pKM101: collaborative study II. Mutat Res. 1998; 412 : 17-31.

24 Leung LK, Su Y, Chen R, Zhang Z, Huang Y, Chen ZY. Theaflavins in black tea and catechins in green tea are equally effective antioxidants. J Nutr. 2001; 131: 2248-51.

25 Khokhar S, Venema D, Hollman PC, Dekker M, Jongen W. A RP-HPLC method for the determination of tea catechins. Cancer Lett. 1997; 114: 171-2.

26 Masuda S, Uchida S, Terashima Y, Kinae N. Inhibitory effect of green tea extracts on nitrosation and epidemiological study on cancer mortality. Environ Mutagen Res. 2004; 26: 265-73.

27 Yang CS, Lambert JD, Ju J, Lu G, Sang S. Tea and cancer prevention: molecular mechanisms and human relevance. Toxicol Appl Pharmacol. 2007; 224: 265-73.

28 Coyle $\mathrm{CH}$, Philips BJ, Morrisroe SN, Chancellor MB, Yoshimura N. Antioxidant effects of green tea and its polyphenols on bladder cells. Life Sci. 2008; 83: 12-8. 